\title{
地上写真測量用図化機
}

$$
\text { ニコンプロッターTR-2について }
$$

丸山孝*

\section{Terrestrial Photogrammetric Plotting Instrument “Nikon Plotter TR-2”,}

by Takashi Maruyama

\begin{abstract}
Recently, the technique of stereophotogrammetry has been introduced in Japan as an effective means of disposing traffic accidents and the fruit is being watched with keenest interest.

To answer such a trend of the market, Nippon Kogaku K.K., who has developed photogrammaetric instruments since long, now has completed a new terrestrial photogrammetric plotting instrument, "Nikon Plotter TR-2".

This "Nikon Plotter" enables not only disposing of the traffic accient but also efficient plotting and measurement in the other topographic and non-topographic fields.

The following is the outline of the "Nikon Plotter TR-2".

まえがき 昨年来, 国内においては交通事故処理等に実体写真測量の技術が導入され，その成果のほどが非常に 注目されている。

当社に扔いても写真測量用機材の開発には年々力を入れてきたが, 今度この新しい市場の要求の一助をになう べく, 更には他の地形学的, 非地形学的分野での高度な実体測定あるいは図化を可能ならしめるものとして, 地 上写真専用図化機ニコンプロッターTR-2 を完成したのでここにその概要について紹介する。
\end{abstract}

\section{TR-2 の設計にあたって}

ニコンプロッター TR-2 を設計するにあたっての 大前提として大体次の 3 つ事項があげられる。

（1）図化機の有可特殊性を充分考虑し，更には， 市場の状況から短期完成を目ざさねばならないという 事情も市って, 当社固有の技術に加えて, ニコンプッ ターM5の長所をそのまま生かすとともに M5 で修得 した技術を100\%生かすことを配慮している。

（2）既に市場にあった海外諸メ一カ一の製品の長所 をできるかぎり取入れ，短所を排除して使いやすい機 械ということを目標とする。

(3) 海外諸メ一カ一の機械には各社それぞれ独特の イメージがあるのでそういったハンチューにできるだ け属さない新しいイメージを打出すべく, 日本光学独 特の機械の完成を目ざす。

以上 3 項を大方満足したものとしてTR-2の完成を みることができた。写真 1 は TR-2 の外観である。

* 日本光学工業株式会社機器設計課

(写真測量) Vol. X No. 11971

$$
\text { ニコンプロッター TR-2 の特徵について }
$$

ニコンプロッターTR-2の有する特徴としては以下 の事項があげられる。

（1）一人で容易に操作ができるようにという配慮か ら投影機構と渵画機構を一つの架台にまとめ簡素化し ている。

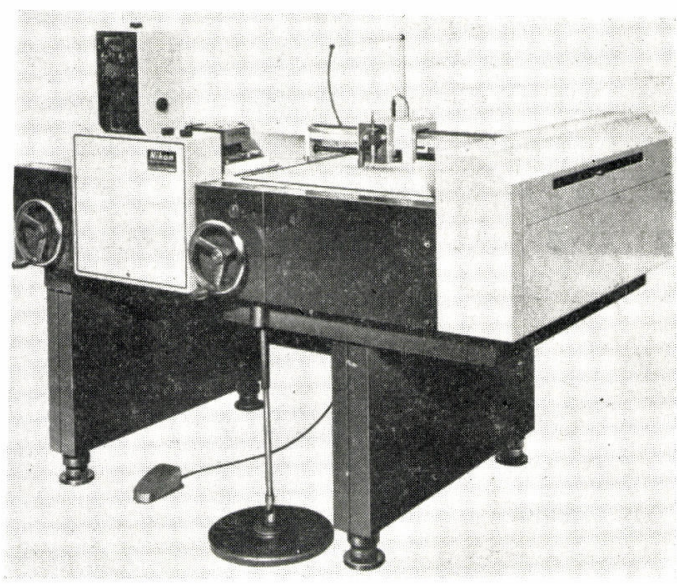

写真 1 


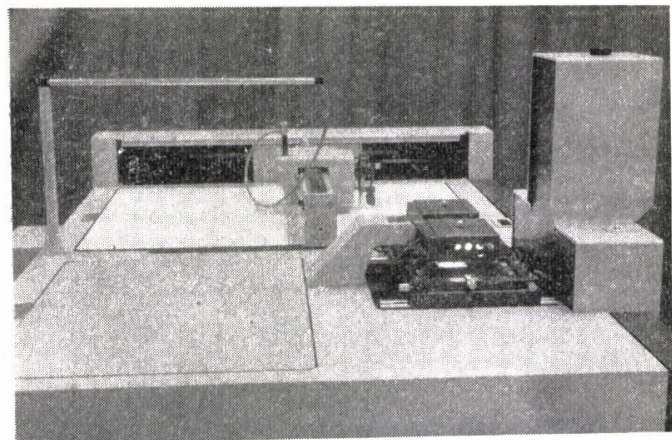

写真 2

(2) 機械設置に要する床面積は非常に少なくて済み 同じ部屋でも広く有效に使用することが可能である。

(3) 機械全体が完全に力バーで保護されているから ほこり，ごみあるいは外力に対して影響をうけること ぶない。

(4) Y-Z のハンドル切換えが簡 単に行なえるから平面図, 立面図は 任意に選択して図化が可能である。

（5）モデル縮尺と図化縮尺ゆ比は ギヤ比を適当に選択することにより 任意に変えうる。

（6）描画台を単独に使用すること b可能であって座標の測定展開等が できる。

(7) 本機とは別により大きな描画 台を別途接続することも容易であっ て, この場合図化機本体に対して全 く任意の場所, オペレーターの都合 のよいところに設置することができる。

（8）困化に際しては描画台上の任意位置よりでき る。

（9）乾板のセットに当っては標定用顕微鏡の使用に より四化機本体の投影, 観察機構之は全く無関係に非 常に短時間で行なうことができる。

(10) 観測系以明るく像の質は非常にすぐれている。 以上の特徵のなかで(1)，(2)，(3)，(5)，(8)，(10)等は二 コンプロッターM5の長所とされるものをそのまま継 承している。宋た，(7)，(9)等は既製の図化機には全く 無い新しい長所ということができよう。

構造

ニコンプロッターTR-2は構造上次の 3 つの部分か ら成っている。

\section{1）交会機構}

ワンマンコントロールを実現するために交会機構 は, $(\mathrm{X}-\mathrm{Y})$ 面と $(\mathrm{Z}-\mathrm{Y})$ 面に分離して描画台下部
に内蔵してある。図1には TR-2 の機構原理が示して ある。作動はそれぞれXハンドル，Yハンドルおよび

Z用足板にて成される。ハンドル類は非常に軽く駆動 でるので長期の使用にも痩労の度合はきわわて少な い。乾板のスキャンニングは $\mathrm{x}$ 万向は対物部がにな い，y 方向は乾板自身が勘くようになっている。

乾板のセットに対しては上下，左右方向への徽小な 動きと部分的な回転が可能となっている。乾板寸法は $90 \mathrm{~mm} \times 120 \mathrm{~mm}$ 以下のものはい-゙゙ん当取付け可能で あり,フィディシャルマークの間隔は $75 \mathrm{~mm}$ 抢よび $76 \mathrm{~mm}$ の二種となっている。

本機構内には bx, by 導入装置, 立面図, 平面図の 描画を任意に選択してかつ操作を容易にするための $\mathrm{Y}-\mathrm{Z}$ 切換装置, コンパージェンスニラー修正装置, 画面距離導入装置, 高さ読及取りカウンターギャボ ックス等が付属する。な扮有効画面距離は $56 \mathrm{~mm} \sim 68$

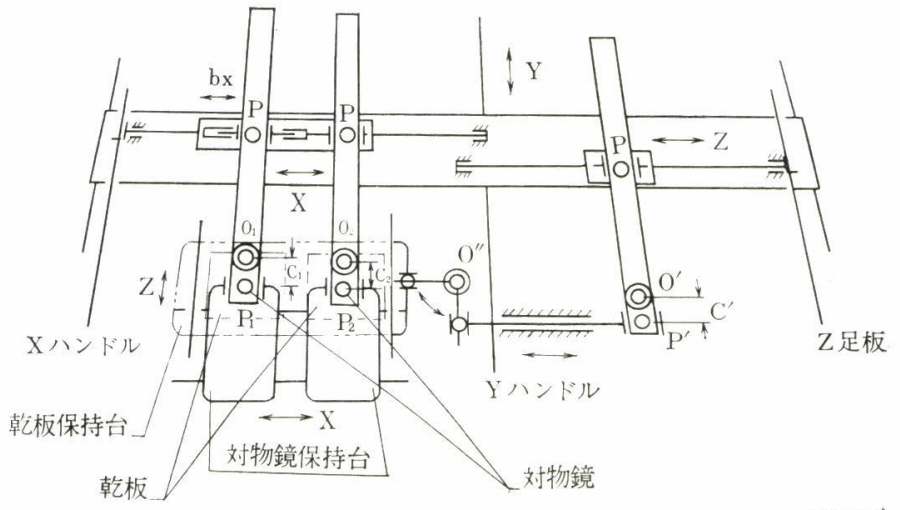

図 1 ニコンプロッターTR-2 の機構

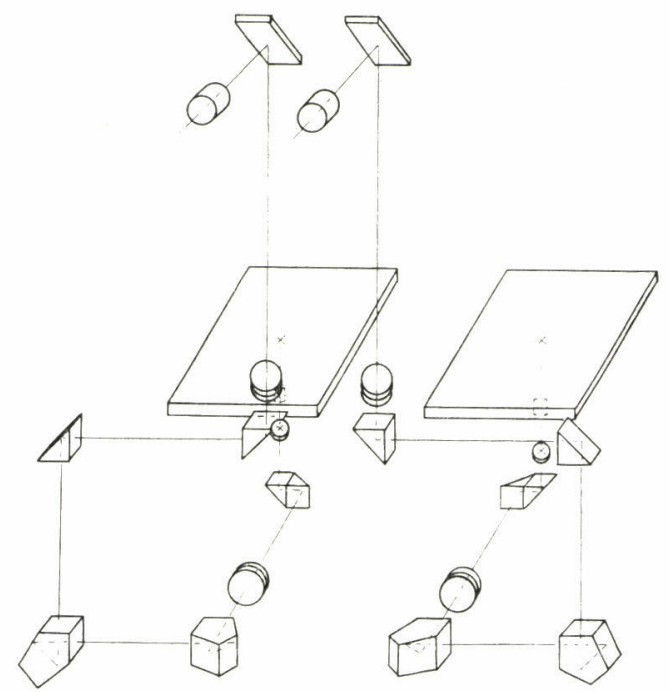

図 2 ニコンプロッターTR-2 光学系 


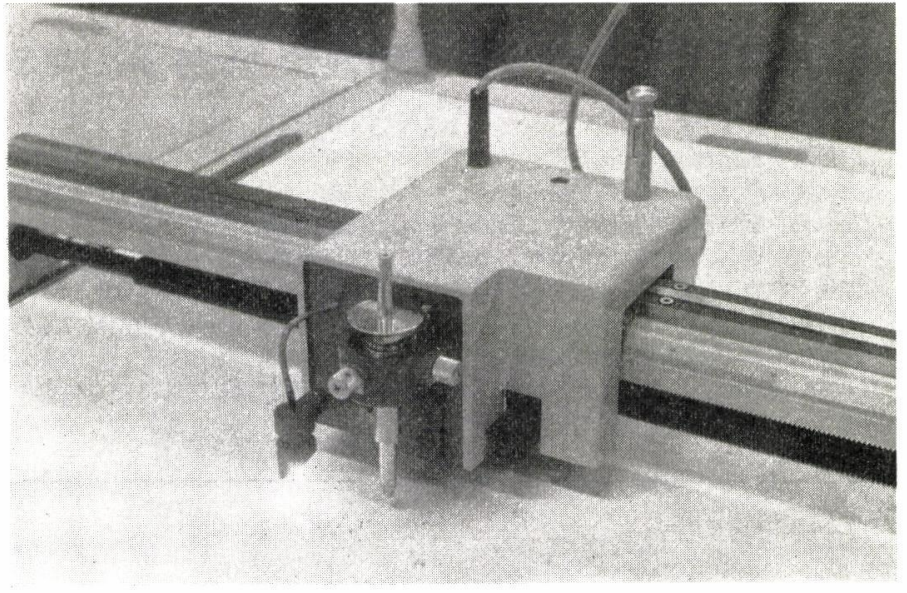

写真 3

mmの範囲がセット可能であるが，これは現在市場に あるステレオカメラの画面距離を考慮して必票最小筰 井に怙さえたもので交って要求によりもっと長くとる ことも可能である。基線要素byに関しても全く同様ギヤ比 のことがいえる。

\section{2) 描画機構}

交会機構において計算されたアナログ量は電気的に 描画台に伝達され $\mathrm{X}, \mathrm{Y}(\mathrm{Z})$ のスピンドルを回転し図 化が行なわ机る。写真 3 にはドローイングポイント部 を示す。描画台は本機上面でオペレーターの前面に位 置し, 図化に関する各種作業は楽な姿勢で行なうこと ができ，非常に能率的である。描画の際は鉛筆ホルダ ーがフットスイッチにより上下する。またドローイン グポイント部の $\mathrm{X}, \mathrm{Y}(\mathrm{Z})$ 方向へのフリーモーション が可能であるから任意位置から図化ができる。

なお要求が心ればより大きな描画台を別途用意する ことが可能である。この場合本機との接続は配線コ一 ドの切換えだけで簡単に行ならことができ，また電気 的接続のゆえにこの新しい描画台はオペレーターに対 し，あるいは部屋の都合により全く任意位置に設置す ることぶ可能である。

\section{3) 観測機構}

図 2 にはTR-2 の光学系配置図が示してある。马真 4 は光学系を内蔵した本機接眼部分である。観測倍率 は $6 \times$, 視野 $27 \mathrm{~mm} \phi$ で明るく見やすい像が得られ る。光学系は一方向の運動の及をにならだけであるか ら精度の面でも非常に有利な㙨構といえよう。またこ のゆえに照明面積が狭くてすむ的全視界にわたって 平均した明るい照明が得られる。

\section{㤬能}

乾板サイズ $90 \mathrm{~mm} \times 120 \mathrm{~mm}$

有効画面サイズ $80 \mathrm{~mm} \times 80 \mathrm{~mm}$ 画面距離
モデルの天きさ

$$
\begin{aligned}
\mathrm{X}= & 400 \mathrm{~mm} \quad( \pm 200 \mathrm{~mm}) \\
\mathrm{Y}= & 80 \mathrm{~mm} \sim 500 \mathrm{~mm} \\
\mathrm{Z}= & 310 \mathrm{~mm} \quad(-150 \mathrm{~mm} \sim \\
& +160 \mathrm{~mm})
\end{aligned}
$$

基線要素 $\quad \mathrm{bx}=0 \sim 40 \mathrm{~mm}$

乾板セット旋回 約 $\pm 2^{\circ}$

$$
\begin{aligned}
& \Delta \mathrm{X} \quad \pm 3 \mathrm{~mm} \\
& \Delta \mathrm{Y} \quad \pm 3 \mathrm{~mm}
\end{aligned}
$$

描画台

\section{描画台寸法 $\quad 670 \mathrm{~mm} \times 850 \mathrm{~mm}$}

有効描画寸法 $500 \mathrm{~mm} \times 500 \mathrm{~mm}$ 観測機構倍率 $6 \times$

視 野 $27 \mathrm{~mm} \phi$

メスマーク $0.08 \mathrm{~mm} \phi$ (乾板上)

眼 幅 $65 \mathrm{~mm} \pm 7 \mathrm{~mm}$

描画台 $\mathrm{X}, \mathrm{Y}(\mathrm{Z}) 1: 1,1: 2$

Zカウンター $1: 1,1: 2$

(要求により $1: 3,2: 3,1: 4,3: 5$

$1: 5$ が可能)

電 源 一次側 $100 \mathrm{~V}, 117 \mathrm{~V}, \mathrm{AC}$

二次側 $24 \mathrm{~V} \mathrm{D} \mathrm{C}$

$6 \mathrm{~V}, 6.3 \mathrm{~V}, 100 \mathrm{~V}$ A C

譏械寸法全幅約 $1585 \mathrm{~mm}$

全奥行 約 $1000 \mathrm{~mm}$

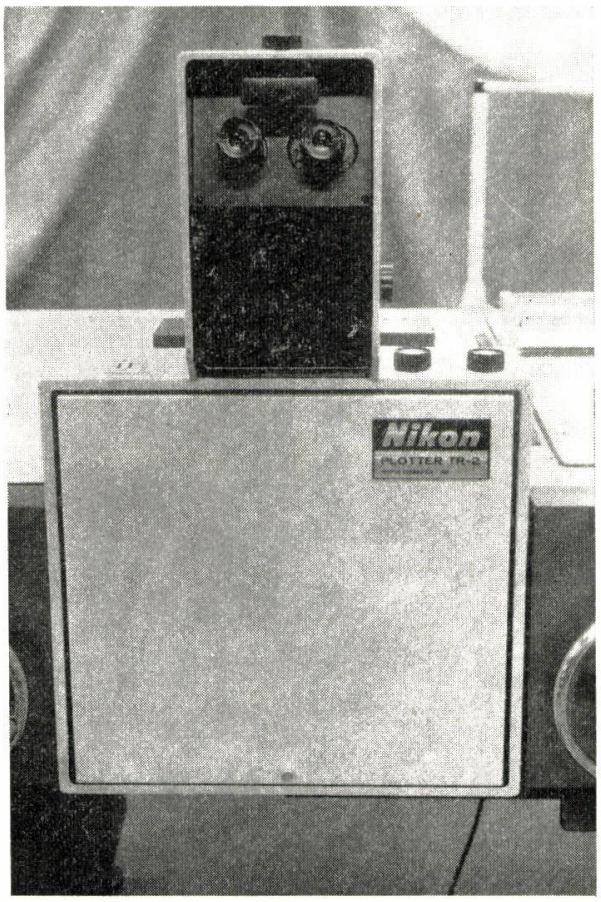

写真 4 
国際写真測量学会第 5 部会のシンポジウムが1970年 9 月 21 日と 22 日の 2 日間に わたってフランスの国土地理院の講堂で世界の各国の専門家55名が参加しておこ なわれた。写真測量の技術で動く物体をいかに測定するかというテーマのシンポ ジウムで, 非常に緩かに動くもの, 早く動くもの, 高速に動くもの, また総括的 な問題を取抖った論文の 4 つの部門に分けて, 研究発表と討議がおうなわれた,

この論文は 2 日目の午後の総打諭文発表の際に, おこなった講演の出容で過去 における日本での動く物体の測定に関しての考え方と諸実例を紹介したものであ る不立分な所もあろらかと存じますので，不備の点は御指摘していたたいて更に 完壁なものにしたいと考えている。

\section{全高約 $1225 \mathrm{~mm}$ \\ 全重量 約 $450 \mathrm{~kg}$}

注1）およびュンバージェンスェラーの修正装置は特別 な装置として標準の機械の場合にはつかない。

注2) 特別付属品として変換ギヤ (1:3,2:3, 1:4, 1:5, 3:5) 刺針用針，観測用顕微鏡，標定用顕微鏡，傾斜換算装置，反 射実体鏡等がある。

ステレオカメラについて

ニコンプロッターは TR-2 現在市場にあるステレオ カメラで撮影した乾板はすべて使用可能となっている が，今度当社に执いてもニコンステレオカメラTS-120 を完成したのでこの誌上を借りて高おせて紹介をす る。

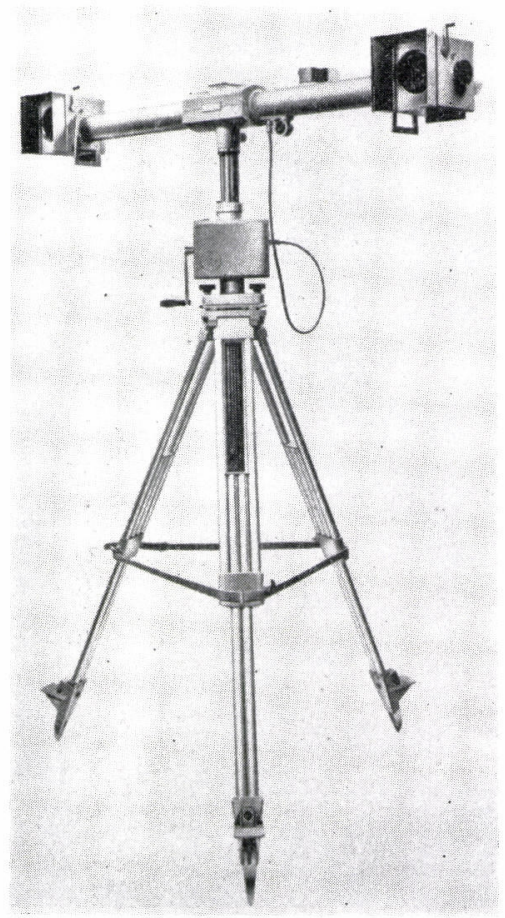

写真 5
主たる特徴としては

(1) 画角加約 $90^{\circ}$ と非常に広角であり，かつ全画面 にわたって歪曲收差は 5 ル以内になっている。

(2) 左右力メラの平行度, 間隔, 内部定位はき扐 て悠密に作られている。

(3) 力xラの光軸は水平に対し, $\pm 30^{\circ}, \pm 60^{\circ}, \pm 90^{\circ}$. の傾斜が可能である。

(4) 乾板サイズは $9 \mathrm{~cm} \times 12 \mathrm{~cm}, 9 \mathrm{~cm} \times 6.5 \mathrm{~cm}$ の ちらも乾板ホルダーの交換に上り使用可能である。

(5) 乾板は下方より挿入するようになって拈り風雨 の影響を受けることがきわめて少ない。

(6) 取扱いミスのない安全確認システムをとってい る。

性能は以下のとうりである。

基線長 $\quad 120 \mathrm{~cm}$

撮影レンズ Geo-NIKKOR

焦点距離 $\quad 60 \mathrm{~mm}$

絞り $\mathrm{F} / 11$ 固定

焦点位置 $9 \mathrm{~m}$ に固定

被写界深度 $5 \mathrm{~m} \sim 50 \mathrm{~m}$

シャッター $\mathrm{B}, 1 \sim 1 / 500, \mathrm{X}$ 接点

使用乾板

$9 \mathrm{~cm} \times 12 \mathrm{~cm}$ または $9 \mathrm{~cm} \times 6.5 \mathrm{~cm}$

有効画面

画角

$8 \mathrm{~cm} \times 10 \mathrm{~cm}$ なな $8 \mathrm{~cm} \times 6 \mathrm{~cm}$

光軸傾斜角度 $93.7^{\circ}$ 索たは $86.7^{\circ}$

気泡管

$\pm 30^{\circ}, \pm 60^{\circ}, \pm 90^{\circ}, 180^{\circ}$

主円型気泡管 $2^{\prime} / 2 \mathrm{~mm}$ 補助円型気泡管 $60^{\prime} / 2 \mathrm{~mm}$

架台 エレベーター式金属三脚 $1.3 \mathrm{~m}$ $2.5 \mathrm{~m}$ または電動式昇降装置 